\title{
Relations between cycling and healthcare network and the case of Curitiba
}

\author{
Relações entre ciclismo \\ e rede de saúde e o caso de Curitiba
}

Hermes Eduardo Nichele [I]

\begin{abstract}
In the present moment of the COVID-19 pandemic, which demands social distancing, the bicycle confirms itself as an advantageous alternative mode. This article reflects on the association between cycling and health through an index proposed to evaluate such association, the Index of Cycling Mobility in relation to the Healthcare Network (in Portuguese, IMCS). The theoretical framework presents the qualities of cycling and the principles that the planning of bike lanes must involve. As a case study, Curitiba's cycling network and its relation to Primary Care Units are analyzed through the IMCS, in the current and projected situations. The results show that Curitiba neglects cycling mobility and that the local healthcare system is practically inaccessible through the cycling network.
\end{abstract}

Keywords: cycling; Covid-19; sustainable mobility; health; Curitiba.

\section{Resumo}

Nesse momento da pandemia da Covid-19, quando surge a necessidade de distanciamento físico, a bicicleta afirma-se como modo alternativo vantajoso. Este artigo dispõe sobre a associação entre ciclismo e saúde através de um índice proposto para avaliar essa relação, o Índice de Mobilidade Cicloviária em relação à rede de Saúde (IMCS). A fundamentação teórica expõe as qualidades do modo cicloviário e as premissas que devem envolver seu planejamento. Como um estudo de caso, o sistema cicloviário de Curitiba e sua relação com as Unidades Básicas de Saúde são avaliados pelo IMCS, em seu estado atual e conforme o plano existente. Os resultados evidenciam que Curitiba negligencia a ciclomobilidade, com o sistema de saúde local praticamente inacessivel pela malha cicloviária.

Palavras-chave: ciclismo; Covid-19; mobilidade sustentável; saúde; Curitiba. 


\section{Introduction}

The outbreak of the disease of the new coronavirus that exploded in 2020 has brought unexpected changes to the routine of cities at the same time it has exposed inequality problems in the urban space. The World Health Organization (WHO) declared the illness, called Covid-19, to be a global pandemic (WHO, 2020b) and recommended the social distancing as a way of prevention, in order to reduce the spread of the virus while vaccines and other effective forms of treatment were not approved (WHO, 2020a).

The social distancing changed the population routine and therefore the scenario of cities and urban mobility. The precariousness of public transport and the problems of motorized individual modes are showed explicitly. The active modes, walking and cycling, arise stronger in the pandemic, given the necessity of physical separation and the maintenance of physical activities (Park, Kim \& Lee, 2020; Teixeira \& Lopes, 2020). Bicycle needs an organized system of proper paths in an effort to act as a fully functional transport mode and the quality of this system depends not only on its extension, but also on aspects like association with usual destinies in the urban environment, which is the case of the health network.

Accordingly, this article intends to analyze the cycling system of a city in relation to its health network through an appropriate index, the Index of Ciclomobility related to the Health Network (IMCS). The case study used is the municipality of Curitiba, in its present scenario and the one designed by the recent Cycling Structure Plan. In order to underpin this analysis, this work seeks to comprehend the advantages of physical and mental health provided by the cycling mode and how the bicycle can be substantial during the pandemic times and the future after.

The article is divided in six sections: this section of (1) "Introduction" presents the subject and the objectives of the work; in (2) "Social distancing, urban mobility and the bicycle" the theoretical foundations about the Covid-19 context and the advantages of bicycle for sustainable mobility are displaced, together with the conception of cycling system and its requirements; the section (3) "Methodological procedures" expresses the work's scientific path; in section (4) "Curitiba's Cycling System" the current situation of the city's cycling network and the general evaluation of 2019's plan are presented; in section (5) "Results and discussion", the IMCS is calculated and the values are critically analyzed; finally, the section (6) "Final considerations" brings conclusive remarks and suggestions to future research.

\section{Social distancing, urban mobility and the bicycle}

The Covid-19 disease, firstly diagnosed at the end of 2019, began to rapidly spread all over the globe and WHO declared it to be a pandemic on March 2020. The fast dispersion and the gravity of the illness are an unprecedented scenario to a globalized and so connected world. In Brazil, one of the most affected countries, the incidence of Covid-19 increased, from October 2020 to April 2021, from approximately 2,290 to 6,028 new cases 
per 100,000 inhabitants, with the mortality rate growing more than the double in the period (Dong, Du \& Gardner, 2020). Thus, once the immunization has slowly progressed, the recommended preventing action by WHO since the outbreak began was social distancing. The physical separation of people is the simplest way to avoid the new coronavirus infection and dissemination. Therefore, several countries applied restrictions to avert agglomerations, the so-called lockdown. During this lockdown, it was necessary the reduction of production activities, trade and services, in an effort to guarantee social distancing. This caused impacts on urban mobility of big urban areas around the world. The habitual capacity of public transport is put in a tight spot in this moment, when people need to be isolated from each other (Teixeira \& Lopes, 2020). The same happens with the motorized individual modes, whose available space in streets enlarged during the quarantine, given the reduction of traffic. Katrakazas et al. (2020) discuss the alterations in the traffic behavior of cities in Greece and Saudi Arabia during the lockdown: increases of velocity and sudden braking, and decrease of commuting.

However, the automobiles and motorcycles, which represent the motorized individual mobility, carry problems like pollution and higher costs. Besides, in normal times, the traffic full of these vehicles leads to congestion and accidents (Alves \& Cunha, 2017; Miranda \& Vieira, 2019).

In Brazilian cities, urban mobility is dominated by the autos. Netto and Ramos (2017) highlight the consequence of the auto-oriented politics, initiated in the period of urbanization expansion, in the middle of twentieth century: a scenario that favors the individual modes. The interests of car industry and real estate market generated sprawled cities, making them dependent on a street network that linked places in a most efficient way. As transit did not received the necessary investments to cover the movement demand, cars and motorcycles became the owners of the public space of streets, making worse the urban segregation and the inequalities related to the right to the city, in according to Carvalho and Britto (2016). The peripherization phenomenon of the cities is thus closely related to urban mobility conditions. The segregation and the exclusion of the less favored classes to the distant urban peripheries, together with precarious public transport systems, foster the individual vehicles fleet's growth (Alves \& Cunha, 2017; Vasconcellos, 2013).

Therefore, Brazil entered the Covid-19 pandemic with its urban areas subordinated to automobile and with deficient and unfit public transport systems. The necessary actions to establish a complete lockdown were fragmented from state to state and from city to city, in the middle of a political crisis. When deployed, in April 2020, quarantine did not have enough duration and strong restrictions to stop the new coronavirus advance, and the commuting kept happening in cities. The journey home-work did not freeze and, making it worse, the buses fleet was reduced in a state attempt to restrict movements. In São Paulo's East Zone, for example, the quantity of buses decreased $61.6 \%$ while the demand lowered at a rate of $63.6 \%$ in the most restrictive period. In the center of the city, the lines in circulation reduced $61.3 \%$, with the demand being cut $68 \%$ of the normal (Giannotti, 2020). These numbers reveal that the volume of passengers followed the transportation availability side 
by side, with the peripheral area having a lower reduction than the central zone one. Besides, starting in May, some deliberations of reopening of trade and services began to occur. After that the situation became a yoyo effect in the following months, between soft shutdowns and recurrent reopenings. This brings a misalignment between demand and capacity of metros and buses, with the impossibility of people practice the social distancing, which deepened the risks of infection by physical contact (ibid.).

This conjecture makes the importance and validity of public transport to be questioned. Aloi et al. (2020) discuss this issue, indicating that cities must to seek alternatives to emphasize the quality and the feasibility of collective modes. And a complementary component to bus, metro, trains, light rail, and other modes that form public transport can be the bicycle.

Bicycle is identified and highlighted as a useful alternative to urban mobility in the middle of this chaotic conjecture that started in 2020. Firstly, in relation to aspects of social distancing, requested in order to avoid Covid-19 infection, the cycling mode is very efficient once it naturally involves separation among people (Park, Kim \& Lee, 2020; Teixeira \& Lopes, 2020).

Furthermore, bicycle acts like a physical activity, which is something weakened with people locked in their homes. WHO recommends at least 150 minutes of moderate physical exercises per week or 75 minutes of more intense activities, practice that Hammami et al. (2020) describe as possible to achieve inside the houses. However, in Brazil this is not a feasible reality to everyone, given the high levels of housings fragility, which also are made explicit in the new coronavirus outbreak (Ramalhoso, 2020). Similarly, it is important to underline that the social isolation requested during the pandemic can trigger the appearance or exacerbation of mental illness, according to Borloti et al. (2020). Considering these circumstances, bicycle shows up as a viable option for both the maintenance of physical activities, once it is properly an exercise, and the mental relief to isolation, since the mode also contributes to mental health (Park, Kim \& Lee, 2020), representing a low cost in acquisition and conservation as well (Miranda \& Vieira, 2019).

Some cities around the world have already registered increasing in the number of people cycling during quarantine. Park, Kim and Lee (ibid.) present data of expansion of the bike-sharing system's utilization in Seoul while Teixeira and Lopes (2020) write about a similar increment happening in the Citi Bike, the New York's bike-sharing program.

And these are the immediate advantages of bike in relation to the Covid-19 disease. Nonetheless, more than an option to social distancing and the maintenance of exercises during pandemic, cycling can be extended also to habitual commuting in urban spaces. In other words, bicycle can work as a utility and predominant mode in the diary journeys of cities. For some time, this ideal is already discussed as a feasible and recommended alternative in the search of a sustainable urban mobility (Carvalho \& Freitas, 2012; Alves \& Cunha 2017). After all, it is a mode that combines a variety of benefits: it requires less space in streets, has flexibility in route's composition, demands less costs of structure 
maintenance, does not pollute the natural environment, and, as already defended, brings gains to physical and mental health, not to mention the low costs to buy it and to conserve it (Nakamori et al., 2015; Miranda \& Vieira, 2019).

It is known the advance of some European cities in the incentive to utility cycling in the last two decades, once they implemented proper structures, with consequent increase in cyclists and decrease in vehicles fleet. Copenhagen, Denmark's capital, is the most outstanding case (Carvalho \& Freitas, 2012; Carvalho \& Brito, 2016). In Brazil, the national laws put the active modes as priority in traffic and mobility politics, at least in theory. The Brazilian Traffic Code (CTB) (Brazil, 1997) defines the preferences attached to bicycle over the motorized vehicles in streets' circulation, when there is not a proper infrastructure.

The Urban Mobility National Policy (PNMU) (Brazil, 2012) is the law set to underpin the urban planning politics in a way that provides full accessibility of people and cargo in cities. In its directives, it is prescribed the priority of non-motorized transportation over the others in order to achieve sustainable urban mobility.

Therefore, it is relevant, for this work's theoretical basis, a brief explanation about the term sustainable urban mobility. Throughout twentieth century, the mobility subject received an essentially technical approach, focusing on traffic engineering solutions. The movements' issue was seen as a disorder in capacity of the traffic meeting demands. Currently, the topic acquired a more qualitative denotation, since it is oriented by the socioenvironmental impacts of transport systems, by the ecological transition that affects energy matrix of countries, and by limits in the sociocultural conjecture of big cities' inhabitants (Araújo-Lima \& Tapie, 2018).

These considerations allow the comprehension of the conception of sustainable urban mobility as the one that embraces the socio-functional necessities in commuting of present time and contributes to environment condition's preservation for future generations (Carvalho, 2016). For this purpose, several modes are taken as priorities: walking, cycling, scooter, skate - the non-motorized modes and buses, tramways, metros, urban trains, water buses, etc. - the public motorized modes. For these collective modes, there must be low impact regarding air emissions, they must be based on renewable fuels, and they need to guarantee efficiency and comfort conditions to people. It is additionally essential the implementation integrated within the street network through mechanisms of urban design that aim universal operability and safety (Del Rio, 1990). Thus, the active transportation (walking and cicyling) appears as a focus that urban development and transport policies must pay attention to, in order to reach sustainable mobility.

However, the culture of ode to cars puts bicycle and pedestrians as secondary in streets and urban planning, leading their commuting to risk situations. Hence, the regulatory policies, like CTB and PNMU, will not be enough while public power does not act effectively towards sustainable urban mobility and discouragement of auto's priority (Carvalho \& Brito, 2016). 
When using bicycles, users face several obstacles in their journeys. The main ones are related to lack of infrastructure, such as cycle tracks, bike lanes and bike racks. With this cycling network not existing, cyclists end up going together with motorized vehicles, dealing with aggressivity of drivers and the small space in street lanes (Battiston, Olekszechen \& Debatin Neto, 2017; Miranda \& Vieira, 2019).

Even with these and other impedances, like topographic and weather conditions, and the actual negative cultural perception about bicycle (Battiston, Olekszechen \& Debatin Neto, 2017), the number of cyclists have increased in the last twenty years as well the research about the issue. Carvalho and Freitas (2012), in a revision work, show that the studies regarding cycling and health started to intensify in 2003. Nakamori et al. (2015) describe the importance of the academic community's support to the discussion of cycling relevance and potentials. In addition, Abílio and Vasconcellos (2017) outline the growing occupation of streets in São Paulo by cyclists, over the years since 2010 .

Therefore, bicycle has overcome the denotation of a mode characterized by recreation and sporadic use, with a cultural conception of contempt. It makes clear the value of utility cycling, the one where the user rides the bike to reach activities of work, study, shopping, services, etc. (Sousa \& Penha-Sanches, 2019; Miranda \& Vieira, 2019).

It is also important to underline the recent increase of bicycle's use as a direct work mode, with the rise of digital platforms of delivery. Through asymmetric associations, between the mobile application and the cyclist deliverers, these undergo long work journeys amid insecurity and street violence. The payment is minimum and there is no guarantee of labor rights, which leads the cyclist to several hours of work, causing fatigue and continuous exposition to traffic dangers. These are the conditions of the called "uberization" of the work, similar to the drivers of applications, but applied to cyclists that turn to this kind of job sometimes because it is the only option of income. During the Covid-19 pandemic, there was an increment in the number of deliveries, since the orders requested in the houses magnified. However, this boost did not reflect in better payments and conditions. To the deliverers, there was no other option than going out to work contacting people, while the distancing recommendations advised the contrary. Thus, this category, which gather both cyclists and motorcyclists, assembled in the movement "App's Brake", organizing a strike at July First 2020 (Peres, 2020).

All of these aspects discussed reveal the problems faced by cyclists in Brazil, from the negative image of the culture which glorifies car until the bad work conditions that involve the application deliverers, going through negligence in policies when they must prioritize the mode and the lack of a good bicycle infrastructure.

Considering this, it is relevant to comprehend how cycling networks should be planned and implemented, taking into account the national context. A creation and the maintenance of a cycling system are required in cities, in order to accommodate cyclists, both the utility and the recreation ones. The system is composed 
of infrastructure and supports to bicycle. The infrastructure is formed by the cycling courses, which involve pavement and sign lighting, and are divided in the following categories in general, according to Tischer (2017), and Cardoso and Campos (2014).

a) Cycle track: an exclusively dedicated space to cyclist, physically segregated from sidewalk and roadway, with safety advantages to the user;

b) Bike lane: a lane within sidewalk or the roadway, keeping pace with the street network, but without a physical separation;

c) Shared space: defines the division of the space with another mode, both in sidewalks and roadways, where the bicycle has preferences to ride, considering pedestrian safety in the case of sidewalks;

d) Bike routes: establishes a schematic and practical way for cyclists over the roadways, usually in local roads with light traffic, counting with the preference of the cyclists, in accordance with the CTB.

The cycling courses can be characterized by being of one or two-way type, as enabled by the width and/or the existence of the correspondent opposite direction. The mode supports embrace proper parking (bike tracks), bicycle sheds, shower facilities and mechanisms of integration with public transport (Nakamori et al., 2015; Vale, 2016).

For the conception and implementation of an efficient and adequate cycling system, some studies and manuals were developed as well some evaluation methods dedicated to existing systems. The Manual of Cycling Planning is a publication made by the extinct Brazilian Company of Transportation Planning
(Geipot, 2001) and compiles recommendations about the creation of a cycling network and about inherent planning aspects. In 2007, the National Urban Mobility and Transport Secretariat, of the extinct Ministry of Cities, published the Reference Guide to Elaborate Cycling Mobility Plans in Cities (Bicicleta Brazil, 2007). It is a booklet addressed to the issue which even revives some appointments of the Geipot's Manual. In 2017, the Institute for Transportation \& Development Policy (ITDP) launched the Guide of Cycling Inclusive Planning, which emphasizes the importance of cyclomobility in its general aspects and gives some directives to project proper bike structures.

Cardoso and Campos (2014) aim at establishing a methodology to plan a cycling system, considering both Geipot's and Biciclet Brazil's documents. Through a bibliographic review and surveys applied to cyclists in Rio de Janeiro, the authors defined five steps that the cycling infrastructure planning should take into account:

Step 1 - Definition of area of influence: the identification of the cycling system must be followed by the recognition of the Travel Generator Poles (TGPs), which are buildings and places capable of acting as a destiny of a high number of trips;

Step 2 - Identification of short ways: through a series of road connections between the TGPs, the most efficient itineraries are established in this step. Vale (2016) points out that the trips up to five kilometers are suitable to make the bicycle the best mode. The cover of similar distances by cycling is also indicated by Nakamori et al. (2015); 
Step 3 - Measurement of qualification of the previous determined courses: Cardoso and Campos suggest calculations of five indicators: effective width of the course; presence of vehicle parking; speed limit; traffic volume; and presence and characterization of slopes;

Step 4 - Proposition of changes in the segments considered inappropriate, based on the finished qualification, which can be solved by choosing near roads or investing in alterations of the existing road network;

Step 5 - Evaluation and suggestion of improvements in the cycling system as a whole.

In all these steps, the popular participation must be considered, with the possibility of supervising and assessing the progress, according to PNMU (Brazil, 2012). The disposition of these premises for the creation of a cycling system is justified by the critical analysis that will be made ahead in the text over the existing situation of the Curitiba's cycling network and the Cycling Structure Plan, projected and approved in 2019 (Curitiba, 2019). Besides, this list of steps shows how it is simple and not expensive the installation of a proper system to bicycle, as Miranda and Vieira (2019) write about.

\section{Methodological procedures}

Based on this theoretical and critical framework, this section presents the methodological procedures in order to analyze the Curitiba's cycling system (existing and projected), from an efficiency's point of view and in association with health aspects. Since it is an investigative issue guided to comprehend a process as a whole, Yin (2005) recommends the use of the case study method, theoretically substantiated. Thus, according to that author, the analytical expansion and generalization happens through the identification of causal linkages of a phenomenon within its context, in a comparation between present and projected future.

The case study used in this article, the phenomenon in question, is the Curitiba's cycling network in relation to the health network, in two moments, the current distribution and the proposed one of the Cyling Structure Plan of 2019 (Curitiba, 2019). For this analysis, it was used the methodological procedure suggested by Vinicius Tischer, environmental engineer and $\mathrm{PhD}$ in Environmental Science and Technology, in his article named "Validation of technical parameters to assessment of urban mobility applied to cycling infrastructure" (Tischer, 2017). The author writes about the scarcity of bibliographic material regarding parameters of cycling systems' assessment and planning in Brazil. This lack of research material was also observed in the search for the construction of the theoretical references for this article. Therefore, utilizing and adapting the Tischer's method imparts validity to a national researcher's work.

The engineer proposes the composition of mathematic parameters starting from the cycling network, in accordance with Graph Theory referenced practices. His objective was to provide a general index of quality to a cycling system, as well as the existing ones of other areas, like Human Development Index (HDI). For the index construction, three parameters are necessary, as the author explains. 
Firstly, there is the cycling network fragmentation indicator, which exposes the deficiencies in integration and continuity of the infrastructure. It is given by Equation 1:

(1)

$$
f=\frac{1}{n_{t}}
$$

Where $f$ is the fragmentation factor; and $n_{t}$ is the number of connected and integrated segments of the cycling network. The higher $f$, more unified and integrated is the network of cycling courses.

The second parameter is cycling system density, which demonstrates the proportion of cycling courses' availability in relation to the road network. It is given by Equation 2

(2)

$$
d=\frac{L_{c}}{L_{a c}}
$$

Where $d$ is the cycling system density; $L_{c}$ is the total extension of the cycling network in the assessed city or area; and $L_{a c}$ is the extension of main roads in the city, namely, the arterials, collectors and others considered as fast traffic or connection. This choice is justified by the greater facility of riding the bike in local roads, of slow and calm traffic, in which the aggressivity of drivers is shorter and the cyclist feels safer (ibid.; Sousa \& Penha-Sanches, 2019). According to the equation, the more main roads flanked by cycling structure, the higher density.

Finally, there is the called parameter gamma $(\gamma)$, generated as Graph Theory says. The links $(L)$ - or segments - would be the pieces of the network and the nodes $(n)$ or vertices - would be road junctions and dead ends of the cycling courses. The gamma indicator is given by Equation 3:

(3)

$$
\gamma=\frac{L}{3(n-2)}
$$

Where $\gamma$ is the routes choice index; $L$ is the number of segments of the cycling network; and $\mathrm{n}$ is the number of vertices in the network. According to the equation, $v$ would have a higher value if the junctions of cycling segments were more leveraged, with greater possibility of routes from a single node. Starting with this wide and general classification, it is necessary the adaptation of the methodology to evaluate the association of the cycling system with health, in the case study of Curitiba.

As previously expatiated, the cycling practice is closely related to the individual's physical and mental health, even more in the case of utility cycling. In order to evaluate the connection between Curitiba's cycling network and the health, the access of the Healthcare Centers (HCs) to cycling courses were explored. This is substantiated by two reasons:

The HCs are places where population seeks for primary attention services of health, such as reception, medical, nursing and dentist consultations, application of vaccines, women's and elderly's health care, drug administration, and several more (Curitiba, 2020). The Health Ministry highlights that $80 \%$ of the health problems are solved in the $\mathrm{HCs}$, making them the responsible for the 
healthy living habits (Health Ministry, 2013). This means these health centers are sought mostly in moments that do not require urgent treatment and do not necessarily impede people from riding a bike;

An adequate cycling system depends on the connection of several places and facilities that attract trips, the so-called Travel Generator Poles (TGPs). Thus, the buildings of a city's health network can be put in this classification, as Cardoso and Campos (2014) defend. According to PNMU (Brazil, 2012, art. 7), mobility should "promote the accessibility to basic services and social facilities", which is the case of HCs.

In other words, the connection of health centers with a cycling system indicates the cover of this very system over basic activities that people practice in the access to the city. Therefore, in order to quantify the correlation between Curitiba's HCs and its cycling network, one more indicator was added to the Tischer's precedent ones, completing the infrastructure evaluation index. It is the indicator delta $(\delta)$, given by Equation 4:

(4)

$$
\delta=\frac{\sum_{i}^{n}\left(\frac{P A_{i}}{P_{i}}\right)}{n}
$$

Where $\delta$ is the cycling network to health network support index; $P$ is the population of the Healthcare Center's coverage area $i ; P A$ is the population served in this area; and $n$ is the number of HCs.

Tischer (2017) gathers the three original parameters in the so-called Index of Ciclomobility (IMCiclo). In the methodology proposed in this work, the fourth parameter is aggregated to the others, shaping the Index of Ciclomobility related to the Health Network (IMCS), given by Equation 5:

(5)

$$
I M C S=100 f d \gamma \delta
$$

Both IMCiclo and IMCS vary from 0 to 100 and they are capable of indicating the general quality of a cycling system, according to a correspondent classification adapted from Tischer's work (ibid.):

$<1$ : one-off and inexistent;

Between 1 and 3: insufficient;

Between 3 and 10: low;

Between 10 and 20: reasonable;

Between 20 and 30: adequate;

> 30: optimum.

With the IMCS attainment predetermined, the methodology of collection and systematization of data related to cycling network involved two software: QGIS and Excel. In QGIS, the geoprocessing of maps was made based on information of the road network, the cycling network, the Curitiba's HCs and population density. The Curitiba's cycling courses were mapped underpinned by data available in the Institute of Research and Urban Planning of Curitiba (IPPUC, 2019), over which some new segments were added, being verified in loco by the author. The served population of each HC's coverage area was obtained through crossing of census data (IBGE, 2010) with isochrones of 500 meters from the cycling courses connected to the Healthcare Center in question. This radius of distance is the recommended for a resolution of a cycling infrastructure, in accordance with ITDP (2017). In excel, in turn, computed data 
originated in QGIS were organized to make possible the execution of the calculations and the fabrication of graphs, adapted into figures and texts.

\section{Curitiba's Cycling System}

Curitiba, capital of Paraná state, had 1,948,626 inhabitants in 2020 (IBGE, 2020) and is known by its historical transport system that innovated the relationship between mobility and planning. The express buses, the trinary system of roads, the exclusive bus lane, and the implementation of the structural sectors of land use densification around transit are the elements that marked the city since the 70's (Nichele, 2018).

Nevertheless, the premise of increasing the density around the bus lane did not avoid the peripherization and the metropolization phenomena. With the land valuation getting higher next to the structural avenues, where the best transit is found, the lower classes were left with occupation in the borders of the city or in nearby municipalities, both through informal occupations and through housing programs' production (Lima et al., 2018).

Besides, the lack of structural reforms in the health system, the bus fare increase, and the whole Brazilian context of incentive of the car industry and the automobile itself made the motorization rate grow in Curitiba, with an elevation of $46.5 \%$ in the general quantity of vehicles between 2007 and 2018 (Detran-PR, 2019). In relation to the automobile quantity, more recent data show that, in 2018, the city had 50 autos for each 100 inhabitants, almost double of the national average in that year,
26 cars for each 100 inhabitants (IBGE, 2020). Meanwhile, the number of public transport users has been declining in Paraná's capital. From 2015 (when the metropolitan integration was ceased) to 2018 , that was a drop of $18.5 \%$ in the quantity of passengers transported in a year (URBS, 2019).

In relation to the cycling mode, that was never a big innovation like happened with public transport in the past century. Starting with a $3 \mathrm{~km}$ shared sidewalk, implemented in 1977, the Curitiba's cycling network had modest increases in extensions (Curitiba, 2019) when compared by a proportion with the whole road network. And these additional provisions did not mean advances in quality. Over the decades, several segments were mischaracterized and did not received maintenance, and the cycling courses in Curitiba became known as simply connections of parks, depicting the mode only as a sporadic recreation (Goetten, 2017; Araújo, 2014).

Figure 1 show some situations found by the author, which is also a utility cyclist, in the cycling network of the city. The first picture exhibits a signage spotted in the segment that flanks the cargo rail in the districts Alto da XV, Hugo Lange and Cabral. This course is officially classified as a cycle track, but is signed and utilized as a shared sidewalk in practice. The second image is a demonstration an incomplete infrastructure, with the lack of a curb ramp that enables bicycles (and pedestrians) to access the shared sidewalk, a situation that puts people in danger while crossing the road. These are just two evidences of the incoherence and precariousness of Curitiba's cycling network. The objective of this work is not to minutely uncover the practical details, although they are relevant for the 
system quality. Instead, what is aimed is the perspective over the general characteristics of the network and its relation to health facilities.

From 2011 to 2018, the extension of Curitiba's cycling network had the most significant increase, growing from 117 to 208 kilometers, according to the cycling plan (Curitiba, 2019). And, between 2019 and 2020 , some more segments were constructed. Therefore, there are 223.3 kilometers of cycling courses in Curitiba (October 2020), which are distributed in six categories (similar to the previously presented), aside from some mischaracterized segments not counted: (1) cycle tracks: exclusive spaces, physically segregated; (2) bike lane on sidewalk: preferential lane close to sidewalk; (3) bike lane on road: preferential line on the space used by cars; (4) shared sidewalk: space shared with pedestrians in the sidewalk; (5) shared roadway: lane shared with vehicles in the toads, with preference of cyclists,

Figure 1 - Situations found in Curitiba's cycling network in 2020

Imagem 1

Sinalization of a shared sidewalk Padre Germano Mayer street (Alto da XV)
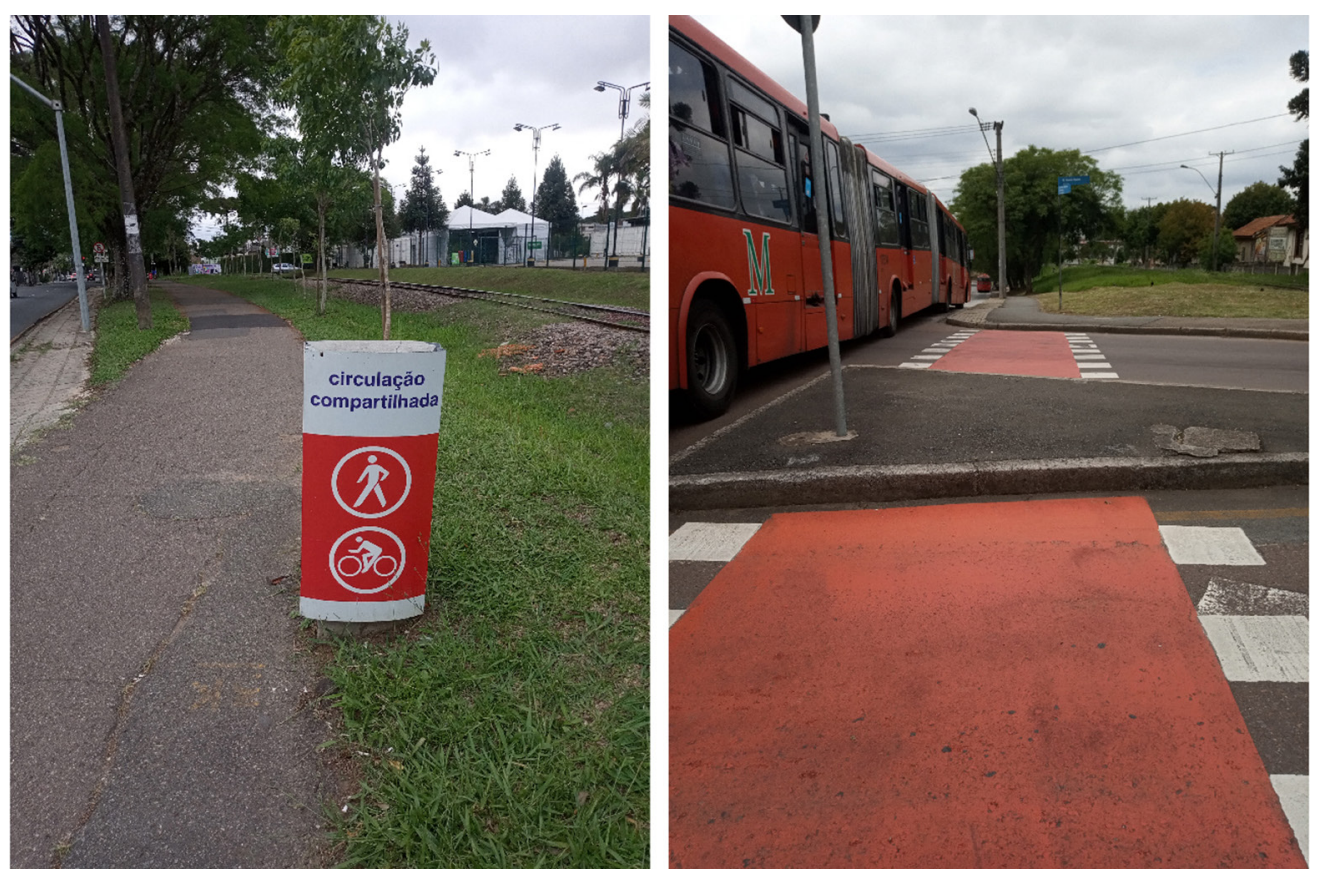

Imagem 1

Lack of curb ramp - Santo André street versus Pres. Alfonso Camargo avenue (Capão da Imbuia)

Source: elaborated by the author (2020). 
Figure 2 - Curitiba's cycling system in present time (October 2020)

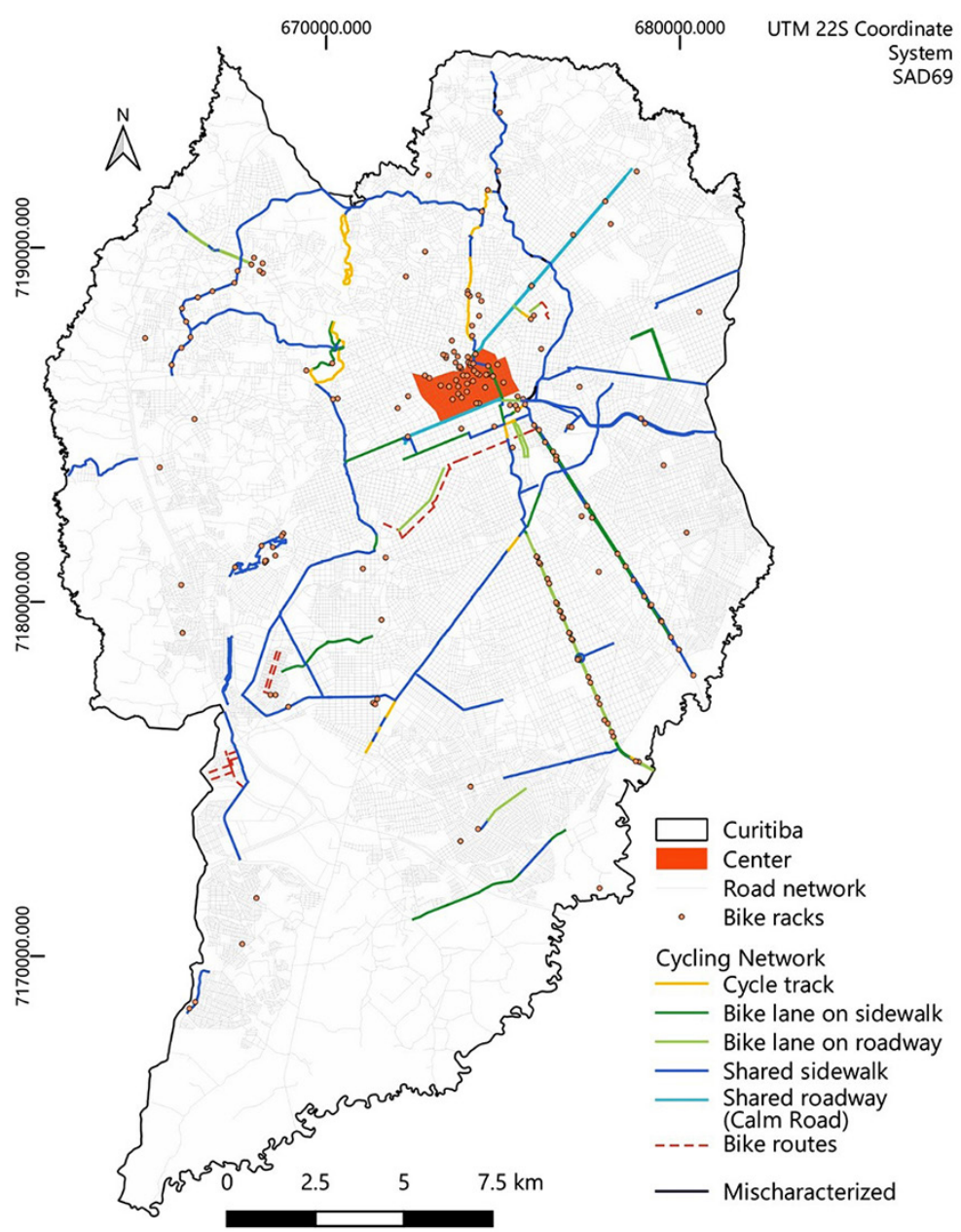

Source: elaborated by author, based on IPPUC (2019).

being called Calm Road; (6) bike routes: use of a local road for the constitution of a route for bicycle, with the division of space with cars. Figure 2 shows the existing network (in October 2020), separated in the six types, presents the bike racks locations, and contextualize the network within the road network of the city.
In the cartogram, it is possible to verify the cycling network's fragmentation, with various disperse and disconnected segments, and some few areas more served. The distribution of bike racks does not keep pace with the network, being more numerous in central areas. In addition, it is notable the predominance of shared sidewalks 
in comparison with other types. Figure 3 presents the proportion of the cycling courses' categories available currently. The vast majority (63.6\%) is composed by shared spaces, while the exclusive use category represents only $6.0 \%$ of the total courses.

In 2019, a municipal decree approved the Cycling Structure Plan (Curitiba, 2019), developed by IPPUC. The plan is underpinned through historical data of the network, mentioning the increase in cars fleet and the necessity of regaining the roads both for pedestrians and cyclists. After that, the document executes an inventory of the existing cycling network, cataloging information like courses' conditions, signage and support facilities. The diagnosis of the plan does recognize the fragmentation of Curitiba's system, the lack of signage and visual identity, and the low integration with buses. The diagnosis also recommends the practice of cycling close to the exclusive bus lanes, neglecting in part the use of bicycle in peripherical districts and the necessity of expanding the network all over the city.

As legal references, the plan mentions the CTB (Brazil, 1997), the PNMU (Brazil, 2012) and the Director Plan of the city, which was revised in 2015 and predicted improvements in the cycling network. Starting of some criteria, the document describes that larger and with more intense traffic roads

Figure 3 - Distribution of the types of cycling courses in Curitiba - 2020

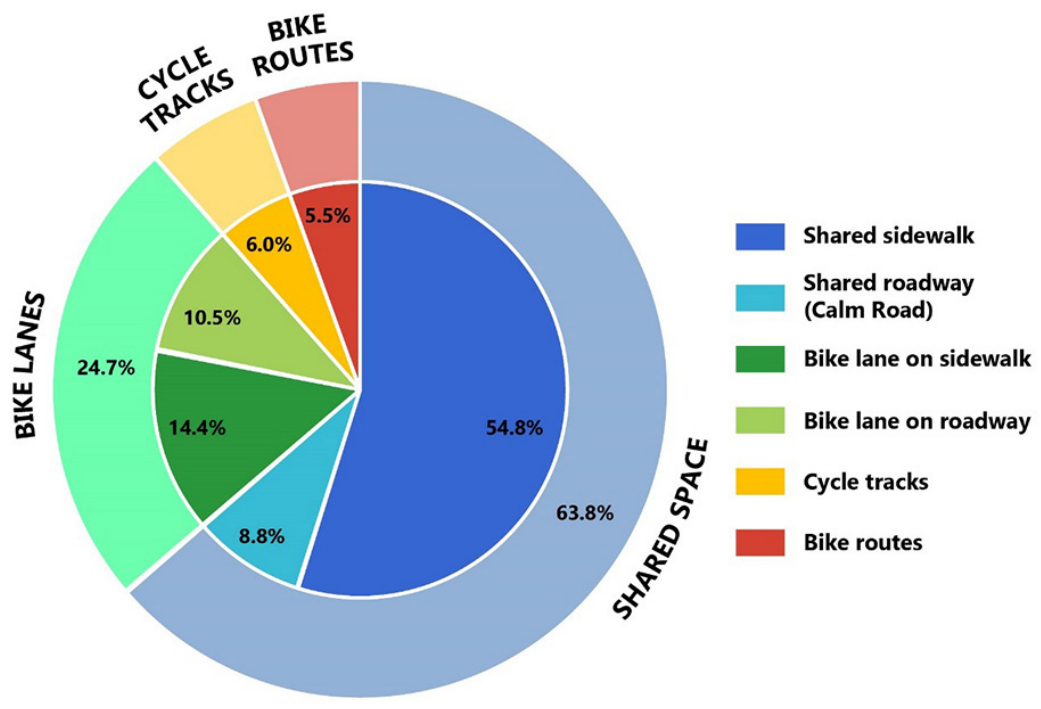

Source: elaborated by author, based on Curitiba (2019). 
require exclusive and segregated lanes for cyclists while, for narrower and low traffic roads, the solution would be to share the space with other modes (pedestrians, in the sidewalk, or cars, in roadways). As directives, the plan estimates the closing of the network, the integration with the BRT corridors, and the association with some big facilities. Figure 4 shows the scheme of the proposed network, counting on these directives.

Figure 4 - Directives of the 2019's Cycling Structure Plan

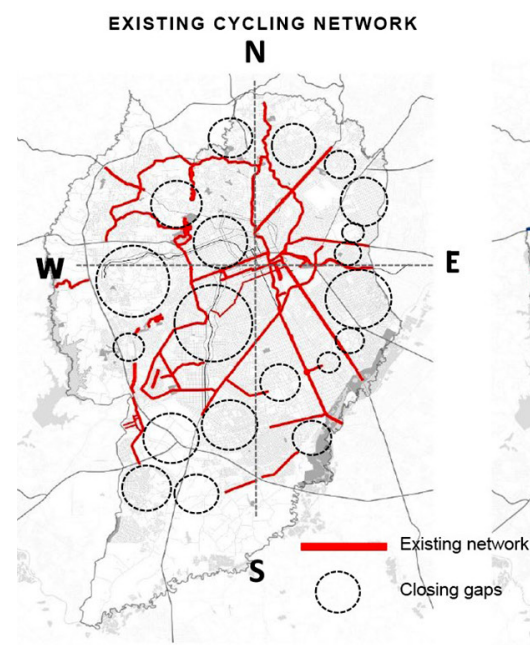

PROJECTED CYCLING NETWORK

INTERMODALITY
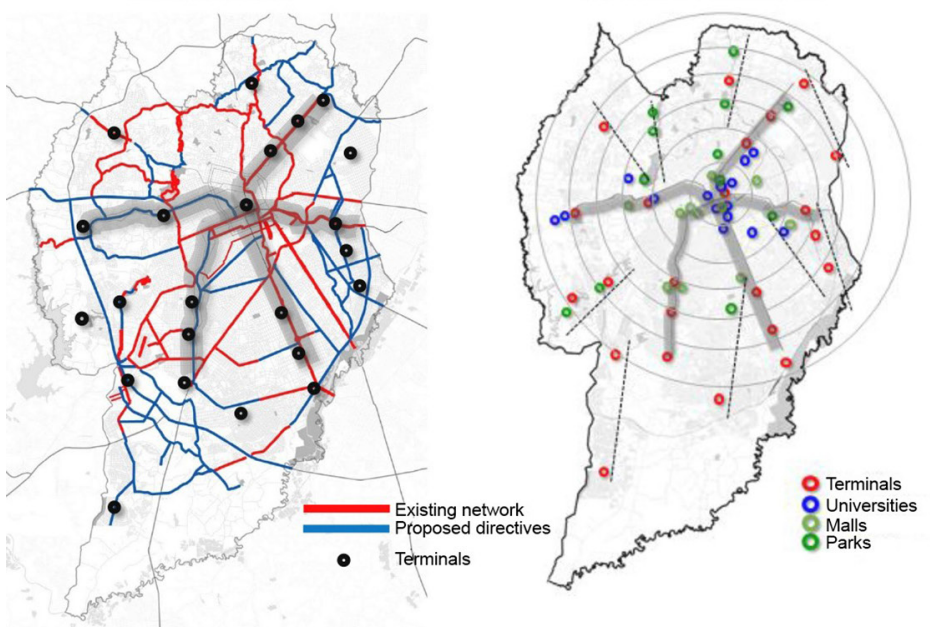

Source: Curitiba (2019). 
It is important to highlight some particularities of the Cycling Structure Plan approved by Curitiba's city hall. The own plan admits to focus on the courses around the express buses and within some districts revealed as intense stage of cycling by an origin-destination study made in 2015. However, this study was made with users spotted in the central areas, favoring the movements in that local and neglecting the peripherical districts and subcenters of commerce and employment.

Another issue is the absence of popular participation in the plan's elaboration. There was even a declaration of rejection directed to the city hall and IPPUC, signed by professors of Federal University of Paraná (UFPR), by engineers and architects, and by the Alto Iguaçu Cyclists Association (Ciclolguaçu) (Senge-PR et al., 2019). The declaration mentions that the discussions with these adviser entities and with the public occurred without a systematized method and in a confusing way, with the suggestions being discarded and ignored in the final document of the plan. In addition, the text emphasizes the massive costs spent by the public power on paving roads, maintaining the automobile priority.

Aside from these critiques about the conception process of the plan, it is relevant to highlight some comments regarding the proposed network, which would be concluded in 2025. In relation to the projected cycling courses, their types are not specified. That means it is not possible to determine if they will be cycle tracks, bike lanes, shared spaces or bike routes. With respect of the destination spots that orientated the proposed courses, the plan mentions some big facilities were used as guides. According to Geipot (2001) and ITDP (2017), these should be the TGPs, identified in a detailed and deep research. Nonetheless, the plan set as important spots of destination only some terminals, universities, malls and parks, as Figure 4 shows. It is an attitude that proves the devaluation of utility cycling and keeps the cultural interpretation of the bicycle as a mode of recreation, also focused in favored classes that go to universities and big shopping facilities. Primary and secondary schools, nurseries, Healthcare Centers, local commerce centers, little parks and squares, service facilities, and convergence spots of bus lines were all put aside.

The proposed network, categorized in accordance with priorities of segments to be constructed, is showed in Figure 5, within the context of the road network, and the location of the HCs and their connections to the system, something which will still be discussed. In the cartogram, it is possible to verify the several loose ends of the network, together with some dense areas with no access to cycling courses at all, problems that the plan claims to solve. The majority of priority segments are close to the transport structural axes, and the peripherical areas have only disperse and inconsistent predict coverage. 
Figure 5 - Curitiba's cycling system proposed by the 2019's plan, together with the HCs

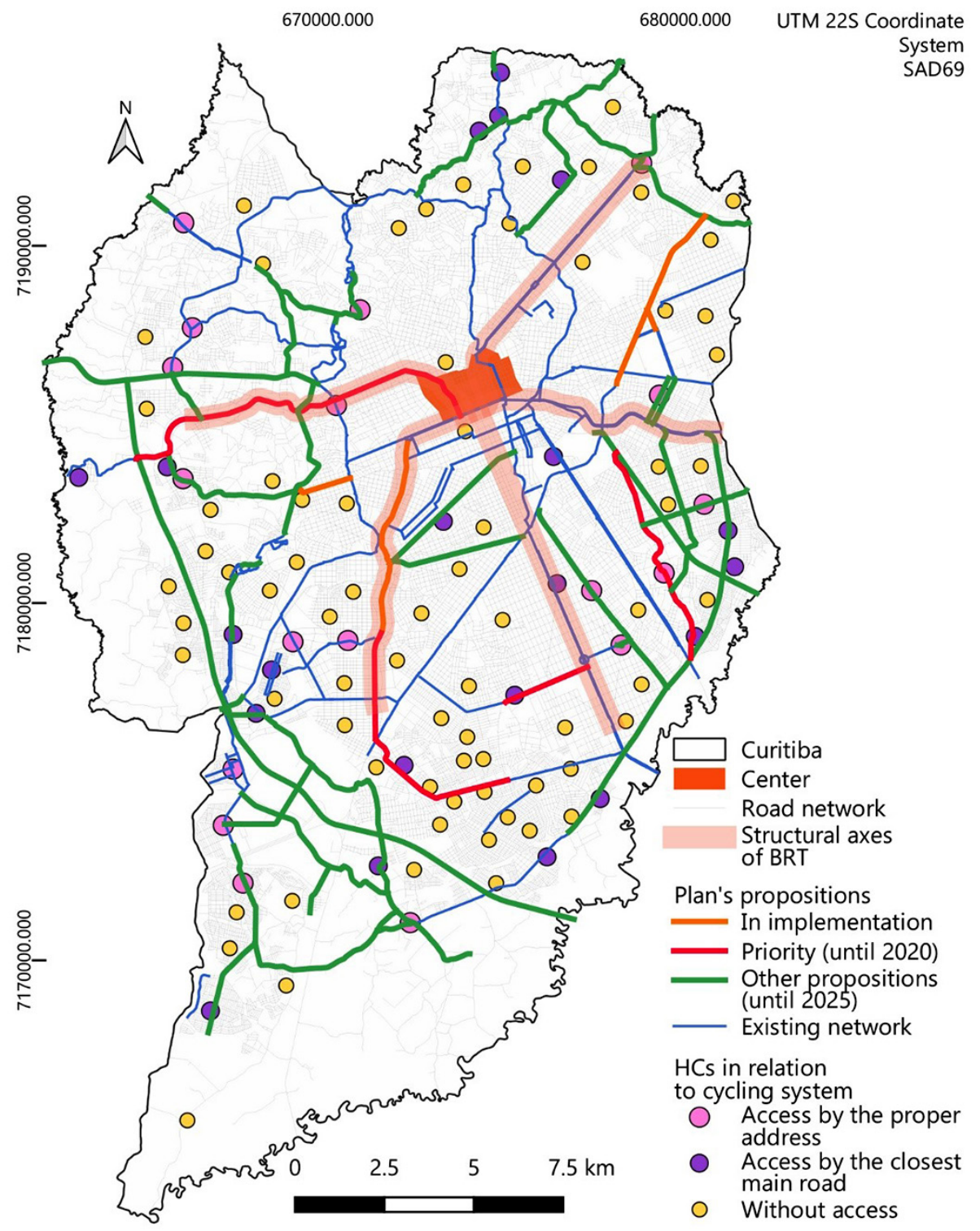

Source: elaborated bt author, based on Curitiba (2019). 


\section{Results and discussion}

With this general assessment of the plan, comes the Curitiba's IMCS calculation and the analysis of the relationship between the health network and the cycling courses of the city, in accordance with the proposed methodological procedures. There are currently $111 \mathrm{HCs}$ in Curitiba and each one has a delimited area of influence, channeling the user by their residential address. Figure 5 shows the HCs location: the ones that will have access to the cycling network when the plan is concluded, both directly (by the proper address) and indirectly (by the closest main road); and the ones that will have no connection. This distribution is not logical, as both the current system and the projected one ignore the HCs as spots to guide the network. Thus, it is a mere coincidence when a $\mathrm{HC}$ is adjacent to or near a cycling course.

The charts of Figure 6 present the proportion of Healthcare Centers connected to the current cycling network and to the proposed courses, approved in the plan. Only 14\% (16) of the total $111 \mathrm{HCs}$ are integrated with some type of cycling course; in the plan, this percentage increases to $34 \%$ (38 out of 111), reflecting the growth in the cycling extension next to the double. In relation to the availability of proper places to park the bicycle, only two HCs have bike racks currently, both of them not being accessed by the actual and the projected network. In addition, the plan does not mention any installation of new bike racks in the city.

Through the calculation of the supporting indicators, the IMCS was generated, both for the current and the projected network of the city, with the values organized in the Table 1.
The present IMCS is 0.06, which classifies the Curitiba's cycling system as one-off, inexistent and with a recreational focus. If all the projected segments were concluded, the city would have the IMCS resulting in 0.63 , an insignificant increase that would not change the classification of the system. The cycling network would only be evaluated as adequate if the IMCS was above 20 , as the designation previously disposed.

The Curitiba's IMCS calculation and the assessment of the current and the proposed scenarios for the cycling network allow some important critical interpretations. The plan is for sure and advance, due to the almost twofold growth in the extension of cycle tracks, bike lanes and alike. But this change is modest and irrelevant when compared with the city's size and necessities. The calculated IMCS for the projected scenario show how Curitiba will still be far from having a satisfactory cycling network.

The plan had yet a controversial construction, disregarding the popular participation and using criteria in a biased manner, without underpinned methodological steps, as the described ones by Cardoso and Campos (2014). The own implementation of the projected segments for the biennium 2019-2020 is delayed: until the end of 2020, 46.4 kilometers should be constructed in this first stage, so-called priority. In October 2020, only two months before this limit, of the 12 segments imagined for this stage, none was finished. Solely 1.1 kilometer was constructed, aside from other 2.9 kilometers made that were not predicted in the document.

In relation to the Healthcare Centers, most are not served and they are disregarded in the proposals for the city's cycling network. The negligence about the HCs and other 
Figure $6-\mathrm{HCs}^{\prime}$ access to Curitiba's cycling system

\section{Access in the current cycling network}

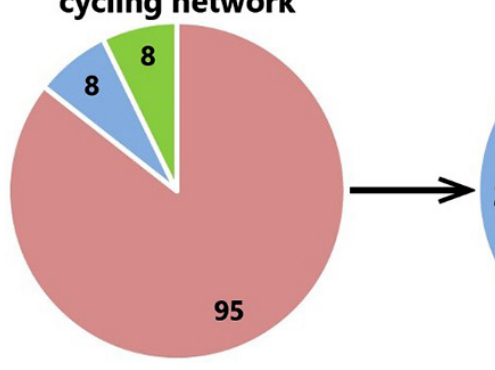

Source: elaborated by author.

\section{Access in the planned cycling network}

18

20

73
Direct access

(by the proper address)

Indirect access (by the closest main road)

Without access

Table 1 - Calculation of Curitiba's IMCSa

\begin{tabular}{|c|c|c|}
\hline Calculation & Current & Projected \\
\hline$n_{t}$ & 13 & 7 \\
\hline$f=1 / n_{t}$ & 0,08 & 0,14 \\
\hline$L_{c}$ & $223.273,26$ & $416.337,42$ \\
\hline $\mathrm{L}_{\mathrm{ac}}$ & $1.007 .002,75$ & $1.007 .002,75$ \\
\hline $\mathrm{d}=\mathrm{L}_{\mathrm{c}} / \mathrm{L}_{\mathrm{ac}}$ & 0,22 & 0,41 \\
\hline $\mathbf{L}$ & 123 & 241 \\
\hline $\mathrm{n}$ & 114 & 183 \\
\hline$\gamma=L / 3(n-2)$ & 0,37 & 0,44 \\
\hline$\delta=\Sigma n i(P A i / P i) / n$ & 0,09 & 0,24 \\
\hline$I M C S=100 \mathrm{fd} \gamma \delta$ & 0,06 & 0,63 \\
\hline
\end{tabular}

Source: elaborated by author.

important TGPs reveals that Curitiba is not in fact concerned about the upgrading of its cycling network's infrastructure, even less about the prioritization of the bicycle, in the modal distribution. Taking service facilities and respective influence areas, like the $\mathrm{HCs}$, could be an essential cornerstone in the composition of directives of cycling courses to be implemented, but is not what is proposed in Curitiba. 
In sum, therefore, the Cycling Structure Plan of Curitiba represents a quantitative increase in the cycling network, which is absolutely appreciated, depending on the effective implementation. However, the plan belittles the cycling importance in the formation of a sustainable and public transport-oriented mobility, ignoring the real necessities and claims of bicycle users. This reveals that Curitiba goes against the current of the establishment of a good cycling system, which could contribute to a more sustainable urban mobility and to people's health, even more in the scenario post-Covid-19.

\section{Final considerations}

Bicycle is the transportation mode to be considered as a priority for a sustainable and affordable urban mobility. The present moment, the pandemic of the new coronavirus, emphasized the advantages of cycling, not only because of the possibility of social distancing and the practice of physical activities, but mostly because of the representation of an alternative to be combined with public transport. This would reduce the pressure over buses, metros, and trains and also remove the automobile of public roads.

This article intended to reunite theoretical evidences about the utility cycling, its importance and its relation to health habits and health facilities. Evaluating and comprehending the existing cycling networks in Brazilian cities is first step that public power must take in order to project effective improvements. The IMCS, the proposed index to assess the cycling system in relation to the health network, becomes a way to analyze the quality of cycling courses in a city as a whole. In the case of Curitiba, the IMCS results in only 0.06 (in a scale from 0 to 100 ), indicating that the cycling system in the Paraná's capital is minimal and disaggregated. The Cycling Structure Plan approved by a municipal decree in 2019, whose elaboration involved contradictions about popular participation, is biased when creates a false bicycle promotion. The near-doubling in the network, which raises the IMCS to a banal value of 0.63 , keeps on considering the mode as a sporadic activity of recreation, without a real concern about sustainable or multimodal mobility. When not paying attention to the quality of its cycling infrastructure, Curitiba is neglecting its population's health, with people kept submitted to a scrapped public transport and the growth in the total of individual vehicles, with all the consequent problems of pollution and congestion.

From the conclusions of this article, other future researches could emerge. The methodological procedures here proposed for the evaluation of a cycling system in relation to Healthcare Centers, including the IMCS calculation, are able to be applied in studies of other cities. The analysis of the connection of the cycling network with the health network can be expanded to hospitals and centers of psychological care. Furthermore, there is opportunity to link cyclomobility's indexes of evaluation with other issues, as aspects of gender, race, classes, land costs, employment places, and integration with public transport. Finally, future proposes could take into account the questions and suggestions put in this work, in order to plan more wide-ranging and fairer cycling networks. 


\section{[I] https://orcid.org/0000-0002-0434-0892}

Federal University of Paraná, School of Architect and Urbanism, Program of Post-Graduation in Urban Planning. Curitiba, PR/Brazil.

he.nichele@gmail.com

Translation: this article was translated from Portuguese to English by the author himself.

\section{References}

ABILIO, C. C. C.; VASCONCELLOS, M. P. (2017). Eu Vou de Bike: a ocupação de bicicletas nos espaços públicos de São Paulo. Ponto Urbe, n. 20.

ALOI, A.; ALONSO, B.; BENAVENTE, J.; CORDERA, R.; ECHÁNIZ, E.; GONZÁLEZ, F.; LADISA, C.; LEZAMA-ROMANELLI, R.; LÓPEZ-PARRA, A.; MAZZEI, V.; PERRUCCI, L.; PRIETO-QUINTANA, D.; RODRÍGUEZ, A. e SAÑUDO, R. (2020). Efects of the COVID-19 Lockdown on Urban Mobility: Empirical Evidence from the City of Santander (Spain). Sustainability, v. 12, n. 3870.

ALVES, J. D.; CUNHA, E. L. (2017). O sistema cicloviário como alternativa para a mobilidade urbana: uma análise em piracicaba - São Paulo. Revista Científic@, v. 4, n. 1.

ARAÚJO, L. (2014). Curitiba terá mais $300 \mathrm{~km}$ de infraestrutura para bicicletas até 2016. Disponível em: http://vadebike.org/2014/05/plano-ciclovias-ciclofaixas-via-calma-curitiba/. Acesso em: 20 out 2020.

ARAÚJO-LIMA, C. de; TAPIE, G. (2018). "La mobilité en question. Les enseignements de Cincinnati (États-Unis) et Curitiba (Brésil)". In: GODIER, P.; OBLET, T.; TAPIE, G. (orgs.). L'éveil métropolitain: L'exemple de Bordeaux. Paris, Le Moniteur, pp. 167-202.

BATTISTON, M.; OLEKSZECHEN, N.; DEBATIN NETO, A. (2017). Barreiras e facilitadores no uso da bicicleta em deslocamentos diários: alternativas para a mobilidade urbana. Revista de Ciências Humanas, v. 51, n. 1, pp. 269-286.

BICICLETA BRASIL (2007). Caderno de Referência para elaboração de Plano de Mobilidade por Bicicleta nas Cidades. Secretaria Nacional de Transporte e da Mobilidade Urbana (do extinto Ministério das Cidades).

BORLOTI, E.; HAYDU, V. B.; KIENEN, N.; ZACARIN, M. R. (2020). Saúde mental e intervenções psicológicas durante a pandemia da Covid-19: um panorama. Revista Brasileira de Análise do Comportamento, v. 16, n. 1.

BRASIL (1997). Lei n. 9.503, de 23 de setembro de 1997. Institui o Código de Trânsito Brasileiro. Diário Oficial da União. Brasília.

(2012). Lei n. 12.587, de 3 de janeiro. Institui as diretrizes da Política Nacional de Mobilidade Urbana. Diário Oficial da União. Brasília. 
CARDOSO, P. D.; CAMPOS, V. B. (2014). Metodologia para planejamento de um de sistema cicloviário. Transportes, v. 24, n. 4.

CARVALHO, C. H. (2016). Texto para discussão n. 2.194 - Mobilidade Sustentável: conceitos, tendências e reflexões. Brasília, Ipea.

CARVALHO, C. O.; BRITO, F. L. (2016). Mobilidade urbana: conflitos e contradições do direito à cidade. Revista de Direito Econômico e Socioambiental, v. 7, n. 2, pp. 103-132.

CARVALHO, M. L.; FREITAS, C. M. (2012). Pedalando em busca de alternativas saudáveis e sustentáveis. Ciência \& Saúde Coletiva, v. 17, n. 6, pp. 1617-1628.

CURITIBA (2019). Decreto n. 1418, de 1ㅇ de novembro. Aprova o Plano de Estrutura Cicloviária e delega competências. Diário Oficial do Município de Curitiba, v. 211, Ano VIII. Curitiba.

(2020). Atenção Primária. Disponível em: http://www.saude.curitiba.pr.gov.br/atencaobasica/atecao-primaria.html. Acesso em: 20 out 2020.

DEL RIO, V. (1990). Introdução ao desenho urbano no processo de planejamento. São Paulo, Pini.

DEMO, P. (1995). Metodologia científica em Ciências Sociais. São Paulo, Atlas.

DETRAN-PR - Departamento de Trânsito do Paraná (2019). Estatísticas de trânsito. Disponível em: http://www.detran.pr.gov.br/Pagina/Estatisticas-de-transito. Acesso em: 26 out 2020.

DONG, E.; DU, H.; GARDNER, L. (2020). An interactive web-based dashboard to track Covid-19 in real time. The Lancet Infectious Diseases, v. 20, n. 5, pp. 533-534.

GEIPOT - Empresa Brasileira de Planejamento de Transportes (2001). Manual de Planejamento Cicloviário. Brasília, Geipot.

GIANNOTTI, M. (coord.) (2020). Boletim 10 - Mudanças no transporte coletivo de grandes cidades aumentaram o risco de contágio dos grupos mais vulneráveis. Rede de pesquisa solidária, v. 10. Disponível em: https://redepesquisasolidaria.org/boletins/boletim-10/mudancas-no-transportecoletivo-de-grandes-cidades-aumentaram-o-risco-de-contagio-dos-grupos-mais-vulneraveis/. Acesso em: 16 out 2020.

GOETTEN, C. (2017). Número de ciclistas cresce em Curitiba, mas infraestrutura segue precária. Brasil de Fato. Disponível em: https://www.brasildefato.com.br/2017/05/15/numero-de-ciclistascresce-em-curitiba-mas-infraestrutura-segue-precaria. Acesso em: 18 out 2020.

HAMMAMI, A.; HARRABI, B.; MOHR, M.; KRUSTRUP, P. (2020). Physical activity and coronavirus disease 2019 (Covid-19): specific recommendations for home-based physical training. Managing Sport and Leisure, v. 25, n. 1-6.

IBGE - Instituto Brasileiro de Geografia e Estatística (2010). Censo Demográfico 2010: Resultados do Universo. Disponível em: https://www.ibge.gov.br/estatisticas/downloads-estatisticas.html. Acesso em: 10 out 2020.

(2020). IBGE Cidades: Curitiba. Disponível em: https://cidades.ibge.gov.br/brasil/pr/curitiba/ panorama. Acesso em: 27 out 2020.

IPPUC - Instituto de Pesquisa e Planejamento Urbano de Curitiba (2019). Dados geográficos. Disponível em: https://ippuc.org.br/geodownloads/geo.htm. Acesso em: 20 out 2020.

ITDP-Instituto de Políticas de Transporte e Desenvolvimento (2017). Guia de Planejamento Cicloinclusivo. Rio de Janeiro, ITDP. 
KATRAKAZAS, C.; MICHELARAKI, E.; SEKADAKIS, M.; YANNIS, G. (2020). A descriptive analysis of the effect of the COVID-19 pandemic on driving behavior and road safety. Transportation Research Interdisciplinary Perspectives, v. 7.

LIMA, C. de; SILVA, M. N. da; TEXEIRA, A. G.; NICHELE, H. E. (2018). Incongruências entre moradia e mobilidade. Conjuntos de habitação popular e o sistema BRT em Curitiba. In: CONGRESSO OBSERVATÓRIO DAS METRÓPOLES 20 ANOS . Rio de Janeiro. Anais... Eixo 2 Gestão e Governança Urbana - Sessão 2.2 Mobilidade urbana. Rio de Janeiro, Observatório das Metrópoles, pp. 381-399.

MINISTÉRIO DA SAÚDE (2013). Entenda a diferença entre UBS e UPA. Disponível em: http://www.blog. saude.gov.br/geral/30302-entenda-a-diferenca-entre-ubs-e-upa. Acesso em: 20 out 2020.

MIRANDA, A. C.; VIEIRA, J. P. (2019). "A bicicleta é o veículo mais sustentável no ambiente urbano". In: ARAÚJO-LIMA, C. (org.). Mobilidade: abordagem multidisciplinar. Curitiba, Setor de Tecnologia, Universidade Federal do Paraná, pp. 96-134.

NAKAMORI, S.; BELOTTO, J. C.; JUNIOR, M. F.; OLIVEIRA, A. G. (2015). A contribuição da academia para mobilidade urbana sustentável por meio do programa de extensão universitária da UFPR Ciclovida. Revista Políticas Públicas \& Cidades, v. 3, n. 2, pp. 145-163.

NETTO, N. A.; RAMOS, H. R. (2017). Estudo da Mobilidade Urbana no Contexto Brasileiro. Revista de Gestão Ambiental e Sustentabilidade, v. 6, n. 2, pp. 59-72.

NICHELE, H. E. (2018). Plano de traçados de linhas estruturais no modal MagLev para o Núcleo Urbano Central da Região Metropolitana de Curitiba - PR: sistema de transporte e mobilidade sustentável. Monografia de graduação. Curitiba, Universidade Federal do Paraná.

OMS - Organização Mundial da Saúde (World Health Organization) (2020a). Coronavirus disease (Covid-19) advice for the public. Disponível em https://www.who.int/emergencies/diseases/ novel-coronavirus-2019/advice-for-public. Acesso em: 15 out 2020.

(2020b). WHO Director-General's opening remarks at the media briefing on Covid-19 - 11 March. Disponível em: https://www.who.int/director-general/speeches/detail/who-director-general-sopening-remarks-at-the-media-briefing-on-covid-19---11-march-2020. Acesso em: 10 out 2020.

PARK, S.; KIM, B.; LEE, J. (2020). Social distancing and outdoor physical activity during the Covid-19 outbreak in South Korea: Implications for physical distancing strategies. Asia Pacific Journal of Public Health, v. 32, n. 6-7, pp. 360-362.

PERES, A. C. (2020). Olha o breque!: movimento dos entregadores vem chamando atenção para a precaridade das relações de trabalho nas plataformas digitais. Radis: Comunicação e Saúde, v. 215, pp. 16-24.

PROGRAMA BRASILEIRO DE MOBILIDADE POR BICICLETA (BICICLETA BRASIL) (2007). Caderno de Referência para elaboração de: Plano de Mobilidade por Bicicleta nas Cidades. Brasília, Secretaria Nacional de Transporte e da Mobilidade Urbana.

RAMALHOSO, W. (2020). Pandemia escancara crise de moradia no Brasil, mas produzir casa adequada para todos é possível e urgente. Ecoa. Disponível em: https://www.uol.com.br/ecoa/reportagensespeciais/moradia-digna-e-prioridade-para-refazer-cidades-pos-covid/\#cover. Acesso em: 24 out 2020 . 
SENGE-PR - Sindicato dos Engenheiros no Paraná; CICLOIGUAÇU - Associação dos Ciclistas do Alto Iguaçu; APUFPR - Associação de Professores da Universidade Federal do Paraná; SINDARQ-PR - Sindicato dos Arquitetos e Urbanistas do Paraná; CRESS - Conselho Regional de Serviço Social do Paraná; IAB/PR - Instituto de Arquitetos do Brasil PR (2019). Nota de repúdio à Prefeitura Municipal de Curitiba e ao IPPUC: Contra a falta de participação na elaboração do Plano Cicloviário e pela ausência de políticas públicas de mobilidade sustentável no governo municipal de Rafael Greca. Disponível em: http://www.senge-pr.org.br/noticia/entidades-criticam-faltade-transparencia-da-prefeitura-de-curitiba-no-plano-cicloviario/. Acesso em: 20 out 2020.

SOUSA, I.-C. N.; PENHA-SANCHES, S. D. (2019). Fatores influentes na escolha de rota dos ciclistas. EURE. Santiago, v. 45, n. 134, pp. 31-52.

TEIXEIRA, J. F.; LOPES, M. (2020). The link between bike sharing and subway use during the Covid-19 pandemic: the case-study of New York's Citi Bike. Transportation Research Interdisciplinary Perspectives, v. 6.

TISCHER, V. (2017). Validação de sistema de parâmetros técnicos de mobilidade urbana aplicados para sistema cicloviário. Urbe - Revista Brasileira de Gestão Urbana, v. 9, n. 3, pp. 587-604.

URBS - Urbanização de Curitiba S.A. (2019). Estatísticas do transporte. Disponível em: https://www. urbs.curitiba.pr.gov.br/transporte/estatisticas. Acesso em: 26 out 2020.

VALE, D. S. (2016). A cidade e a bicicleta: uma leitura analítica. Finisterra, v. 51, n. 103, pp. 45-66.

VASCONCELLOS, E. A. (2013). Mobilidade urbana: O que você precisa saber. São Paulo, Breve Companhia. YIN, R. K. (2005). Estudo de caso: planejamento e métodos. Porto Alegre, Bookman.

Received: Octover 30, 2020

Approved: January 31, 2021 